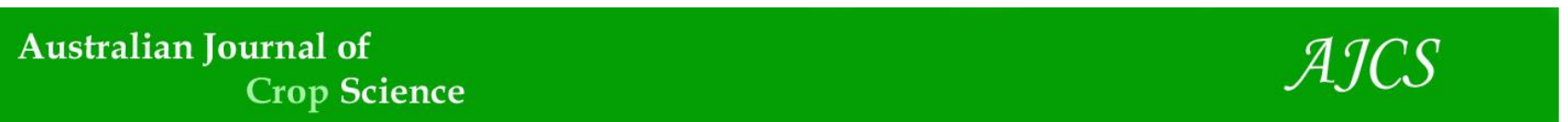

AJCS 15(05):773-779 (2021)

ISSN:1835-2707

doi: 10.21475/ajcs.21.15.05.p3193

\title{
Effect of glyphosate and glufosinate on nutritional content and agronomic performance of maize possessing cp4epsps and pat transgenes
}

\author{
Gabriel Viana de Araújo', Alfredo Junior Paiola Albrecht', Leandro Paiola Albrecht', Hudson Wallace \\ Pereira de Carvalho², Rafaela Alenbrant Migliavacca ${ }^{3}$, André Felipe Moreira Silva ${ }^{3 *}$
}

\author{
'Federal University of Paraná, Palotina, PR, Brazil \\ 2University of São Paulo, Nuclear Energy Center in Agriculture, Piracicaba, SP, Brazil \\ ${ }^{3}$ Crop Science, Palotina, PR, Brazil
}

*Corresponding author: afmoreirasilva@hotmail.com

\begin{abstract}
The aim of this study was to check the tolerance level of maize possessing the transgenes cp4epsps and pat, exposed to high rates of glyphosate or glufosinate. Field experiments were carried out in 2016/17 at the first growing season; and the other in the second growing season, in Palotina, state of Paraná (PR), Brazil. The design was completely randomized block with 4 replications, which were set up with variations of rates of herbicides: glyphosate $\left(0 ; 2,160 ; 4,320 ; 6,480\right.$ and 8,640 $\mathrm{g}^{2} \mathrm{e}^{-1}$ ) (experiment 1) and glufosinate $\left(0 ; 1,500 ; 3,000 ; 4,500\right.$ and $6,000 \mathrm{~g}_{\text {ai ha }}{ }^{-1}$ ) (experiment 2$)$. The application was performed at the V4 stage. Plants were evaluated for injuries, final plant height, stem diameter, 100-grain mass, yield and content of $\mathrm{P}, \mathrm{K}, \mathrm{S}, \mathrm{Fe}, \mathrm{Cu}$ and $\mathrm{Zn}$. The results show that there was no reduction in yield and 100-grain mass, as well as changes in nutrient contents, even with the use of high rates of glyphosate and glufosinate. This is explained by the rapid recovery of maize hybrids under favorable developmental conditions. Despite causing injuries and decreased height, application of glyphosate (up to $8,640 \mathrm{~g}$ ae ha-1) or glufosinate (up to 6,000 ai ha $^{-1}$ ) did neither reduce yield and 100-grain mass nor the nutrient contents of grains. This shows the high selectivity of these herbicides. Nonetheless, crop injury and reduction in height were observed in maize plants for herbicide application. This indicates the risks of using herbicides above the rates recommended in the package insert, despite the absence of deleterious effects on yield.
\end{abstract}

Keywords: chemical control; crop injury; herbicides; morphological response; herbicides selectivity; Zea mays. Abbreviations: ae_acid equivalent; ai_active ingredient; DAA_days after application; D_stem diameter; EPSPs_5enolpyruvylshikimate-3-phosphate synthase; GS_glutamine synthase; H_height; LL_Liberty Link; M_100-grain mass; PAT_phosphinothricin N-acetyltransferase; RR_Roundup Ready; RR2_Roundup Ready 2; Y_yield.

\section{Introduction}

The natural competition between the crop of interest and weeds generates significant yield losses. Estimated, world grain production is affected by $13 \%$ (Stiegelmeier et al., 2016). Weed control consists of the adoption of practices that culminate in the reduction of infestation, the level of control depends, among other factors, on the weed species, crop and methods employed (Lorenzi, 2014).

In the past, several herbicides were used on weeds and crops to find out which one was selective, however, today a single herbicide may show selectivity for several plant species, due to the transfer of genes that confer tolerance to a particular molecule. As an example of this advance, Roundup Ready (RR) technology has been widely accepted by farmers because of the effective weed control using a previously non-selective product (Albrecht et al., 2014).

The "first generation" of glyphosate herbicide tolerant maize (RR) refers to the transgenic event GA21 (Roundup Ready and Agrisure GT). Glyphosate tolerance is conferred by the mepsps gene (modified epsps gene from Zea mays), which encodes an enzyme EPSPs insensitive to this herbicide (Sidhu et al., 2000). The "second generation" of glyphosate tolerant maize (RR2) is represented by events NK603 (Roundup Ready 2 maize) and MON87427 (Roundup Ready maize). Tolerance is conferred by the cp4epsps gene from Agrobacterium tumefaciens strain CP4 that encodes a glyphosate-insensitive EPSPs enzyme (Ridley et al., 2002).

Event T25 confers tolerance to the herbicide glufosinate in maize (Liberty Link ${ }^{\mathrm{TM}}$ - LL). Tolerance is conferred by the pat gene from the bacterium Streptomyces viridochromogenes (Matsuoka et al. 2001). In addition, insect-resistant maize Bt11 and TC1507 events - also has tolerance to glufosinate since the pat gene was used as a marker in its selection process (Silva et al., 2017; Albrecht et al., 2021).

Glyphosate inhibits EPSPs (5-enolpyruvylshikimate-3phosphate synthase) not allowing the transformation of shikimate to chorismate, resulting in lack of aromatic amino acids (phenylalanine, tyrosine and tryptophan), dysregulation of plant carbon flux and accumulation of toxic 
intermediate compounds (shikimate-3-phosphate and shikimate). It has a broad spectrum of action, its action is systemic, being absorbed by leaves and green tissues, and preferentially redistributed by phloem to the meristematic tissues of the plant (Oliveira Júnior, 2011).

Glufosinate is a non-selective contact herbicide that binds to GS (glutamine synthase) which is an important enzyme in the metabolic pathway of nitrogen uptake. As a result, there is accumulation of ammonia inside the cell, decreased photosynthesis, lack of amino acids and accumulation of substances such as glyoxylate (which is a potent inhibitor of rubisco) and toxic oxygen radicals that lead the plant to death (Oliveira Júnior, 2011). A more recent study indicates that glufosinate is mainly toxic to plants due to a lightdependent generation of reactive oxygen species, rather than ammonia accumulation or inhibition of carbon assimilation. The generation of reactive oxygen species causes lipid peroxidation of cell membranes and rapid cell death (Takano et al., 2019).

The effects of glyphosate on nutritional content and/or yield in tolerant transgenic crops have been studied for soybean (transformed cp4epsps) (Zobiole et al., 2012; Albrecht et al., 2018). However, these studies are less consolidated for glyphosate tolerant maize. More recently, Reddy et al. (2018) observed no deleterious effects for two glyphosate applications ( $870 \mathrm{~g}$ acid equivalent - ae - ha-1) on the nutritional content and yield of maize (transformed cp4epsps). For glufosinate tolerant maize (transformed pat), there are also few studies on the effects of this herbicide on nutritional content and agronomic performance. Costa et al. (2018) reported no negative effects of glufosinate $(300+300$ $\mathrm{g}$ active ingredient $-\mathrm{ai}-\mathrm{ha}^{-1}$ ) on nutritional content and yield of maize (transformed pat).

The maximum recommended single application rate of glyphosate for maize (transformed cp4epsps) is $1,080 \mathrm{~g}$ ae $\mathrm{ha}^{-1}$. For glufosinate, $600 \mathrm{~g}$ ai ha-1 in maize (transformed pat) (Rodrigues \& Almeida, 2018). High rates of herbicides (out of the range recommended in the package insert) are known to aggravate resistance problems (due to selection pressure), increase control costs per area, cause damage to cultivated plants, and cause environmental damage, but they comprise a practice still performed by some farmers.

In this sense, it is believed that rates above the recommended in package inserts of glyphosate and glufosinate may affect the nutritional content and agronomic performance of transgenic maize with cp4epsps and pat genes. Thus, the aim of this study was to evaluate the nutritional content and agronomic performance of maize with the transgenes cp4epsps and pat, subjected to the application of glyphosate or glufosinate.

\section{Results}

\section{Regression analysis}

The regression analysis indicated a significant effect $(P \leq$ 0.05 ) of glyphosate rates on the variables: crop injury, at 7 , 14 and 21 DAA and plant height, for the $1^{\text {st }}$ growing season. For the $2^{\text {nd }}$ growing season, on crop injury at 7, 14 and 21. The regression analysis indicate no significant effect of glyphosate rates on the other variables $(P>0.05)$ (Supplementary Table).

For glufosinate, it was observed a significant effect $(P \leq 0.05)$ of the rates on the following variables: crop injury at 7,14 , 21 and 28 DAA and plant height for both growing seasons. Analysis indicated no significant effect $(P>0.05)$ of glufosinate rates on the other variables for both growing seasons (Supplementary Table).

\section{Glyphosate rates effect}

When significant effect was detected, increasing glyphosate rates increased the percentage of crop injury and reduced plant height (Figures 1 and 2), with linear model adjustment. The crop injury was $7.25 \%$ for the rate $8,640 \mathrm{~g}$ ae ha-1 at 21 $D A A$, in the $1^{\text {st }}$ growing season (Figure $1 C$ ). For the $2^{\text {nd }}$ growing season, at $21 \mathrm{DAA}$, an injury of $2.75 \%$ was also found for the highest rate $(8,640 \mathrm{~g}$ ae ha-1) (Figure 2C). It is noteworthy that despite the crop injury, no deleterious effects of glyphosate rates on yield and 100-grain mass were observed for both harvests. The same was verified for the contents of nutrients, evaluated in the $2^{\text {nd }}$ growing season.

\section{Glufosinate rates effect}

With increasing rates of glufosinate, an increase in crop injury was observed for all evaluations and a reduction in maize plant height for both growing seasons (Figures 3 and $4)$, with linear model adjustment. For the highest rate $(6,000$ $\mathrm{g}$ ai ha- $\left.{ }^{-1}\right)$, injury was observed at $27.0 \%$ ( $1^{\text {st }}$ growing season) and $20.3 \%$ ( $2^{\text {nd }}$ growing season) at 28 DAA (Figures 3D and $4 \mathrm{D})$. Similar to glyphosate rates, there were no deleterious effects of glufosinate rates on yield and 100-grain mass for both harvests. Likewise, no significant effect on the contents of nutrients was observed.

\section{Discussion}

Glyphosate application was selective for maize (transformed cp4espsps) at rates 720, 1,440, 2,160 and 2,880 $\mathrm{g}^{2}$ ae ha-1, with no negative effects on height and no crop injury, according to research by Albrecht et al. (2016). Similarly, Krenchinski et al. (2018a) did not observe reductions in chlorophyll indices, height, diameter and yield of maize for glyphosate application $\left(1,080 \mathrm{~g}\right.$ ae ha- $\left.{ }^{-1}\right)$. Other studies also report glyphosate selectivity for maize (transformed cp4espsps) at rates 1,260 $\mathrm{g}_{\text {ae }} \mathrm{ha}^{-1}$ (Ganie et al., 2017), 1,080 $\mathrm{g}$ ae ha-1 (Giovanelli et al., 2018).

The results verified in the present study agree with the previously mentioned studies. Nevertheless, higher rates of glyphosate (up to $8,640 \mathrm{~g}$ ae $\mathrm{ha}^{-1}$ ) were applied in the present study, and despite the crop injury, no reductions in grain yield and nutrient content were detected. It is noteworthy that the maximum recommended rate of glyphosate for application in tolerant maize is $1,080 \mathrm{~g}$ ae ha-1 (Rodrigues \& Almeida, 2018). Thus, high rates are not recommended for weed management, despite being used in some situations by some farmers.

Soltani et al. (2018) observed crop injury, and in some situations even reductions in maize yield (transformed cp4epsps) for glyphosate application $\left(1,800 \mathrm{~g}^{2}\right.$ ae ha-1) in association with 2,4-D. This result may be related to a higher absorption of 2,4-D by maize plants, due to the adjuvants present in the glyphosate formulation, and/or the glyphosate rate used. It is believed that the application of glyphosate at the rates used in the present study, in case of combination with other herbicides could reduce maize yield. This reinforces the recommendation to use glyphosate only up to the maximum recommended rate in the package insert as a precautionary principle. There are descriptions of different side effects generated by herbicides, effects that may be considered latent in the plant of interest. These include changes in nitrogen metabolism, hormone levels and secondary plant metabolism (Rizzardi et al., 2003). When 

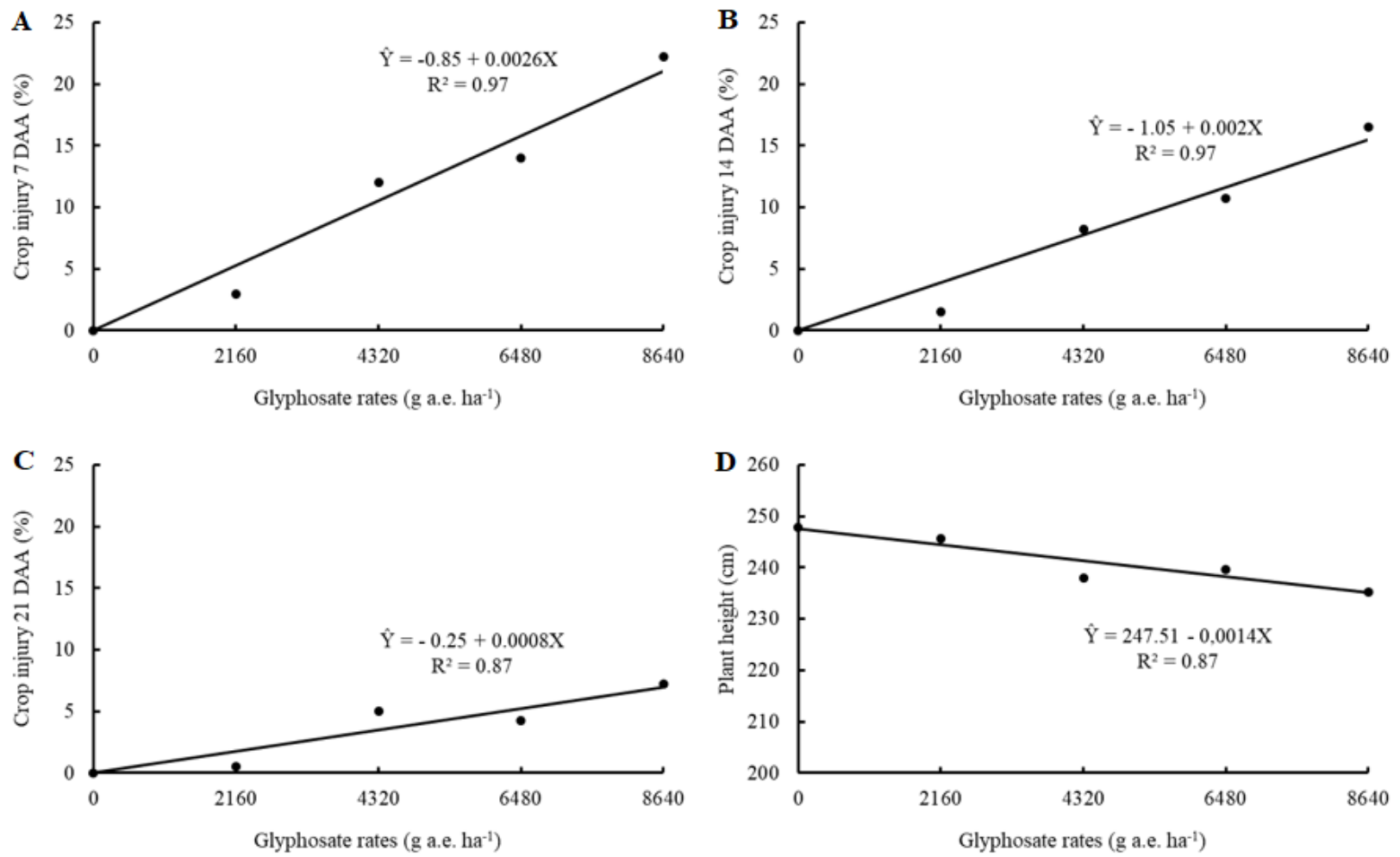

Figure 1. Crop injury at 7 (A), 14 (B) and 21 (C) DAA and plant height (D) of maize plants, under glyphosate rates application at postemergence. Palotina, PR, Brazil, 2016/17 (Experiment 1, 1st growing season).
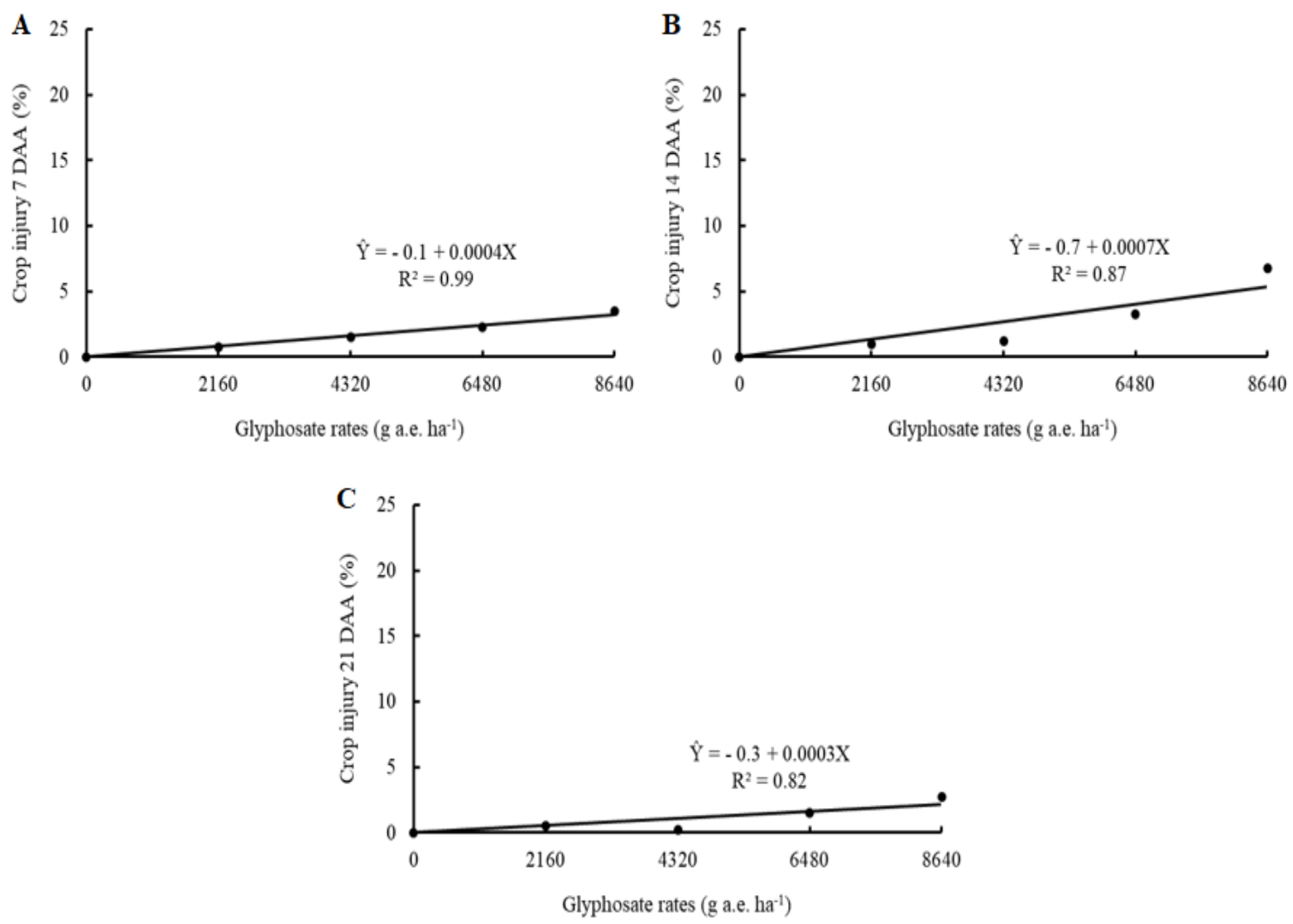

Figure 2. Crop injury at 7 (A), 14 (B) and 21 (C) DAA in maize plants, under glyphosate rates application at post-emergence. Palotina, PR, Brazil, 2016/17 (Experiment 1, 2nd growing season). 

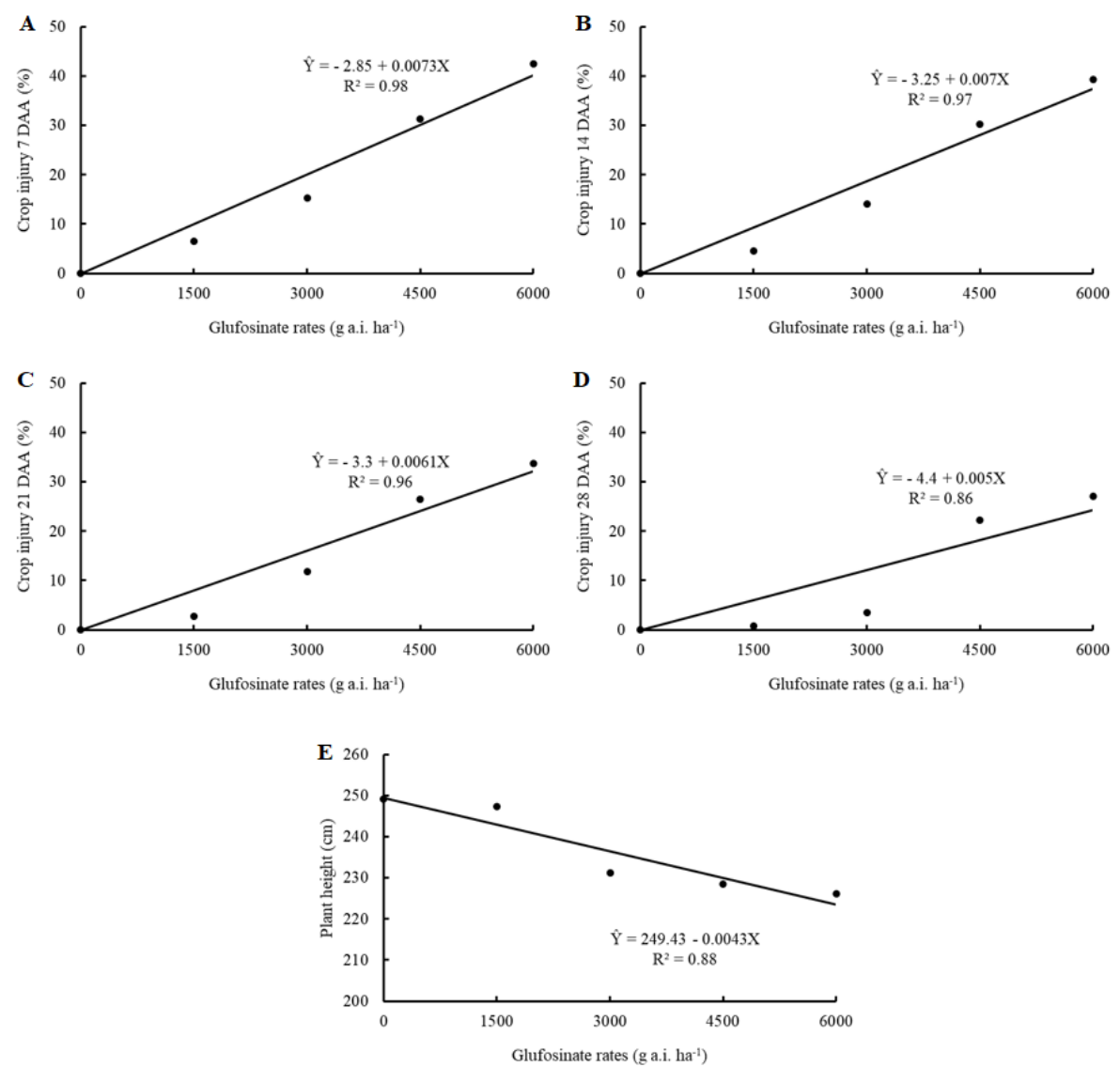

Figure 3. Crop injury at 7 (A), 14 (B), 21 (C) and 28 (D) DAA and plant height (E) of maize plants, under glufosinate rates application at post-emergence. Palotina, PR, Brazil, 2016/17 (Experiment 2, 1st growing season).
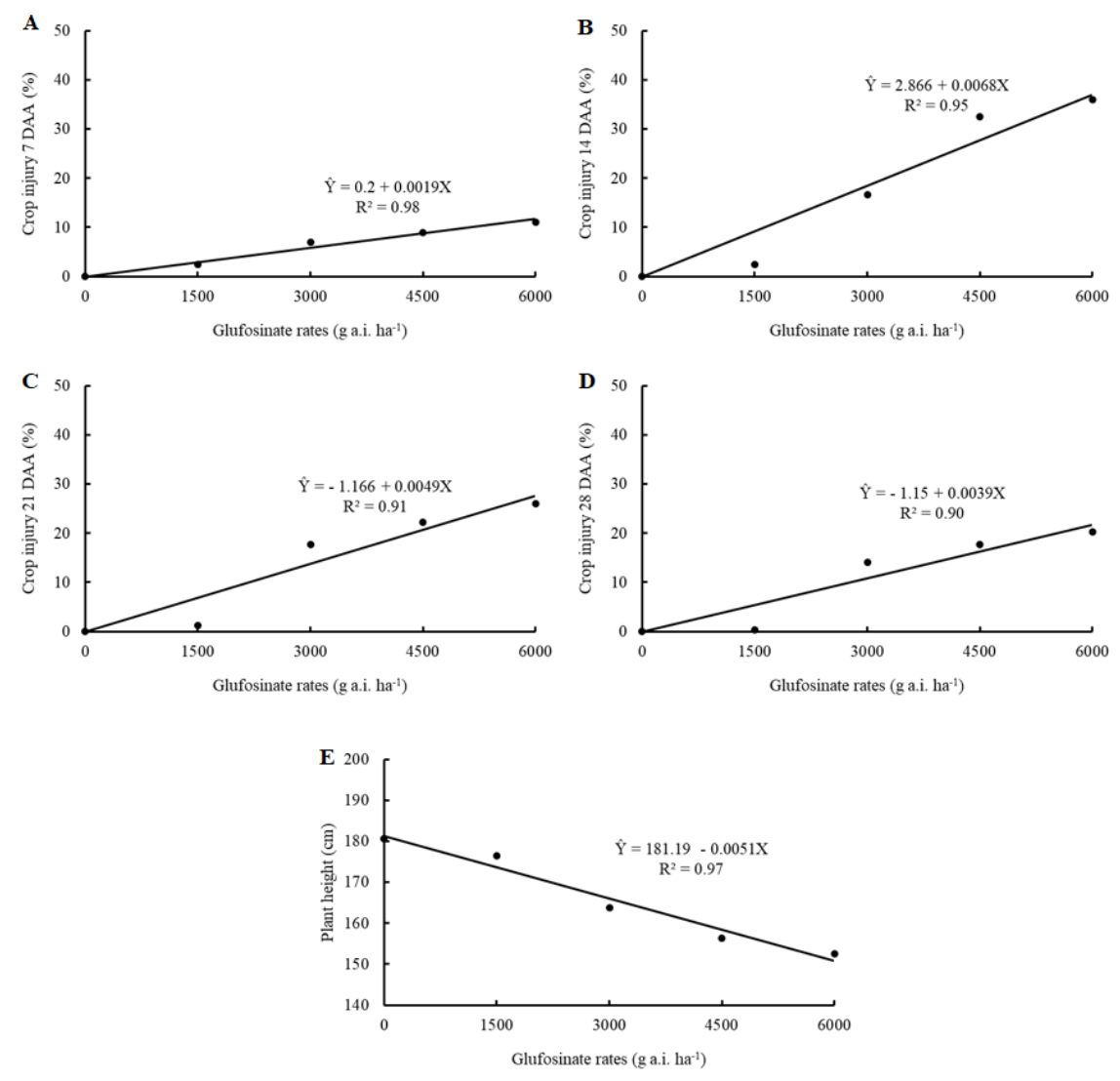

Figure 4. Crop injury at 7 (A), 14 (B), 21 (C) and 28 (D) DAA and plant height (E) of maize plants, under glufosinate rates application at post-emergence. Palotina, PR, Brazil, 2016/17 (Experiment 2, 2nd growing season). 
thoroughly analyzed, the relationship that glyphosate could have with these side effects, it is noticeable that in unmodified plants the herbicide leads to the reduction of aromatic amino acid biosynthesis among them tryptophan (Moreira et al., 2007). Tryptophan is a known precursor of indolylacetic acid, a plant growth promoting auxin (Taiz \& Zeiger, 2010). By analyzing the mechanism of action of glyphosate and how it acts, without taking into account herbicide insensitivity, it can be assumed that the injury caused would lead to reduced growth, as observed for the first growing season for plant height, however, the same result was not observed in the second harvest.

Regarding the nutrient content of the grains for glyphosate application, no changes were verified, which corroborate Reddy et al. (2018) for the application of glyphosate at the rate $870 \mathrm{~g}$ ae ha-1. Correia \& Santos (2013) also observed no effects of glyphosate $(1,200 \mathrm{~g}$ ae ha-1 $)$ on leaf contents of $\mathrm{N}$, $\mathrm{P}, \mathrm{K}, \mathrm{Ca}, \mathrm{Mg}, \mathrm{S}, \mathrm{B}, \mathrm{Mn}$ and $\mathrm{Zn}$ maize plants. Again, in these studies, the rates used of glyphosate are lower than those used in the present study, showing the high tolerance of transgenic genotypes to this herbicide.

Ganie \& Jhala (2017) observed crop injury between 2 and $12 \%$ for glufosinate application (590 $\mathrm{g}$ ae ha-1) in maize (transformed pat) in different chemical management programs. However, they did not observe reductions in maize yield, as verified in the present study. As well as Krenchinski et al. (2018a) did not register reductions in chlorophyll indices, height, diameter and yield of maize for glufosinate application (500 g ai ha-1). Glufosinate selectivity was also found for maize (transformed pat) at rate $500 \mathrm{~g}$ ai ha $^{-1}$ (Silva et al., 2017). Costa et al. (2018) found no negative effects of glufosinate $\left(300+300 \mathrm{~g}\right.$ a.i. ha $\left.\mathrm{h}^{-1}\right)$ on $\mathrm{N}, \mathrm{P}, \mathrm{K}, \mathrm{Ca}$, $\mathrm{Mg}, \mathrm{S}, \mathrm{Mn}, \mathrm{Fe}, \mathrm{Cu}$, and $\mathrm{Zn}$ contents and maize yield (transformed pat). Such information corroborates the results of the present study.

In the present study, crop injury of up to $27.0 \%$ and reductions in height were observed, however, without reductions in yield for glufosinate application. It is noteworthy that the rates $(6,000 \mathrm{~g}$ ai ha-1) were higher than those used in the abovementioned studies, and above the maximum recommended rate in the package insert $(600 \mathrm{~g}$ ai $\mathrm{ha}^{-1}$ ) (Rodrigues \& Almeida, 2018). As for glyphosate, also for glufosinate, rates above the recommended should not be used; however, it is practical that occurs in some situations. The results of the present study indicate some undesirable effects when high rates are applied, characterizing the potential for risk.

The pat gene encodes the phosphinothricin $\mathrm{N}$ acetyltransferase (PAT) enzyme; this enzyme inactivates glufosinate through acetylation reactions (Murakami et al., 1986), so that the herbicide does not reach its site of action, forming non-toxic compounds, metabolizable by the plant. As the rate used is much higher than usual, it is assumed that the reaction of transformation of glufosinate into nontoxic by-products is not so rapid as to avoid all symptoms, aggravated by its elevation, thus explaining the injury observed even with the presence of the enzyme.

Insect-resistant maize (Bt11 and TC1507 events) also has tolerance to glufosinate since the pat gene was used as a marker in its selection process. For example, Agrisure ${ }^{\circledR}$ Duracade $^{\mathrm{TM}}$ 5222, Agrisure $^{\circledR}$ Viptera $^{\mathrm{TM}} 2100$ (Viptera $^{\mathrm{TM}}$ 2), Agrisure $^{\circledR} \quad$ Viptera $^{\mathrm{TM}}$ 3100, Agrisure $^{\circledR}$ Viptera $^{\mathrm{TM}} 3110$ (Viptera $^{\mathrm{TM}}$ 3), Agrisure $^{\circledR}$ Viptera $^{\mathrm{TM}} 3111$ (Viptera $^{\mathrm{TM}}$ 4), Agrisure $^{\mathrm{TM}} \mathrm{CB} / \mathrm{LL}(\mathrm{TL})$, SmartStax ${ }^{\mathrm{TM}}$, Herculex ${ }^{\mathrm{TM}}$ I, Leptra ${ }^{\circledR}$,
Optimum $^{\text {TM }}$ Intrasect, Power Core ${ }^{\mathrm{TM}}$, among other combinations of these insect-resistant transgenic technologies are tolerant to glufosinate because of the pat gene in the selection process (Silva et al., 2017; Krenchinski et al., 2018b).

According to Krenchinski et al. (2018b), pat gene expression is proportional to the level of tolerance to glufosinate. Pat gene expression was as follows Leptra > Power Core > Optimum Intrasect $>>$ Herculex I > Agrisure TL = Viptera 3. Therefore, there may be differences in selectivity for application of glufosinate in maize (transformed pat).

As already mentioned, glufosinate influences the metabolic pathway of nitrogen absorption; this nutrient in turn is constituent of amino acids, coenzymes, alkaloids, nucleotides, chlorophyll and others. Its availability is almost always a limiting factor, directly influencing plant growth more than any other nutrient (Bredemeier \& Mundstock, 2000). This helps to explain, for example, the decrease in height of maize plants with increasing rates of glufosinate, which may have transiently affected the $\mathrm{N}$ balance in the plant, and thus its growth.

Importantly, any stress can have a negative effect on the normal growth and development of the plant (Taiz \& Zeiger, 2010). However, according to Morô \& Damião Filho (1999), even presenting strong crop injury due to the use of an herbicide, production can still be higher because of weed control. The response of the plant to herbicide application may or may not result in injury, which in turn is characteristic of the species and of the product in question. The effect is a result of complex interactions between the plant, herbicide and the environment.

The results show that there was no reduction in yield and 100 -grain mass, as well as changes in nutrient contents, even with the use of high rates of glyphosate and glufosinate. This is explained by the rapid recovery of maize hybrids under favorable developmental conditions. The plants were able to recover from stress even at lower height and develop reproductive structure normally. Although not having impacts on yield, it is noteworthy that the use of high rates (out of the range recommended) of chemical pesticides can generate both economic and environmental losses.

\section{Materials and methods}

\section{Design and experimental conditions}

The experiments were carried out in the field, in Palotina, State of Paraná (PR), Brazil. In experimental area with very clayey soil, whose chemical and physical analysis showed; P: $10.00 \mathrm{mg} \mathrm{dm}^{-3}$; C: $14.11 \mathrm{~g} \mathrm{dm}^{-3}$; K: $0.22 \mathrm{cmol}_{\mathrm{c}} \mathrm{dm}^{-3}$; Mg: 1.04 cmolc $\mathrm{dm}^{-3} ; \mathrm{H}+\mathrm{Al}$ : $\mathrm{cmol}_{\mathrm{c}} \mathrm{dm}^{-3}$; cation exchange capacity (CEC): $10.98 \mathrm{cmol}_{\mathrm{c}} \mathrm{dm}^{-3}$; Al: $0.10 \mathrm{cmol}_{\mathrm{c}} \mathrm{dm}^{-3}$; sum of bases (SB): $5.22 \mathrm{cmol}_{\mathrm{c}} \mathrm{dm}^{-3}$; Zn: $5.13 \mathrm{mg} \mathrm{dm}^{-3}$; Fe: $24.78 \mathrm{mg} \mathrm{dm}^{-3}$; Mn: $22.98 \mathrm{mg} \mathrm{dm}^{-3}$; $\mathrm{Cu}: 9.25 \mathrm{mg} \mathrm{dm}^{-3} ; \mathrm{pH}\left(\mathrm{CaCl}_{2}\right)$ : 4.64; V: $47.54 \%$; sand: $16.25 \%$, silt: $15.00 \%$; clay: $68.75 \%$. The climate of the region is Cfa according to the Köppen classification. Rainfall and temperature data during the experimental period are illustrated in Supplementary Figure. Experiment 1 consisted of the application of glyphosate rates $(0 ; 2,160 ; 4,320 ; 6,480$ and $8,640 \mathrm{~g}$ ae ha-1) (Roundup Ready ${ }^{\circ}, 480 \mathrm{~g}^{2}$ ae $\mathrm{L}^{-1}$, Monsanto do Brasil Ltda, Brazil). Experiment 2 consisted of the application of the rates $(0$; 1,$500 ; 3,000 ; 4,500$ and $6,000 \mathrm{~g}$ ai ha-1) of glufosinate (Finale ${ }^{\circledR}, 200 \mathrm{~g}^{\text {ai L }} \mathrm{L}^{-1}$, Bayer S.A., Brazil). The experimental 
design used was randomized blocks with four replications. Both were conducted in the first growing season (24344'539"S 53858'537'W) and the second growing season (240346'748"S 53861'839"W) of 2016/17. In the first growing season, it was used the hybrid 30F53 VYHR (Leptra RR2 technology), sown on October 24, 2016 and harvested on March 09, 2017. For the second growing season, the 2B10 PW (Power Core ${ }^{\mathrm{TM}}$ technology) hybrid was sown on February 02, 2017 and harvested on July 02, 2017. Both hybrids have tolerance to glyphosate and glufosinate, conferred by the cp4epsps and pat genes, respectively.

Herbicide applications were performed post-emergence, at V4 stage of maize plants, via a $\mathrm{CO}_{2}$ constant pressure backpack sprayer, equipped with a bar with four XR 110.015 fan-type nozzles and pressure of $2.5 \mathrm{kgf} \mathrm{cm}^{-2}$, with a volume corresponding to $150 \mathrm{~L} \mathrm{ha}^{-1}$. For the first growing season, the applications of both experiments occurred on November 18 , 2016, under the conditions of T: 26.3 우; $\mathrm{RH}: 54.0 \%$ and wind speed: $5.5 \mathrm{~km} \mathrm{~h}^{-1}$. While for the $2^{\text {nd }}$ crop, on March 11, 2017, under T: 30.0 - C; RH: $59.9 \%$ and wind speed: $2.8 \mathrm{~km} \mathrm{~h}^{-1}$. Fertilization was carried out with $300 \mathrm{~kg} \mathrm{ha}^{-1}$ of the formulated N-P-K (10-15-15), and the plots were kept free from weed interference by hand weeding. $0.45 \mathrm{~m}$ row spacing was used, with 3 plants $\mathrm{m}^{-1}$. The experimental units consisted of plots of six rows and $4 \mathrm{~m}$ in length.

\section{Evaluations and data collection}

For all evaluations, the four central rows were considered, discarding the first and last meters, which was considered the useful area. The crop injury was evaluated at 7, 14, 21 and 28 days after application (DAA), through a visual scale from 0 to $100 \%$, where 0 represented the absence of symptoms and $100 \%$ the plant death (Velini et al., 1995).

Variables related to agronomic performance were evaluated: plant height (height from the ground to the last leaf just below the tassel), stem diameter ( $2^{\text {nd }}$ internode above the ground level, smallest diameter section), yield and 100 -grain mass. For height and stem diameter, 10 plants were evaluated per plot.

The plants of the useful area of each plot were threshed in an experimental grain thresher. Afterwards the yield was determined, with the values extrapolated to $\mathrm{kg} \mathrm{ha}^{-1}$, and 100 -grain mass. For both variables, the grain moisture was corrected to $13 \%$, and for 100 -grain mass, two repetitions were measured per plot.

For the second growing season, it was also evaluated the content of the nutrients $\mathrm{P}, \mathrm{K}, \mathrm{S}, \mathrm{Fe}, \mathrm{Cu}$ and $\mathrm{Zn}$ for harvested grains, using an $\mathrm{X}$-ray fluorescence equipment; samples were sieved through a 100-mesh sieve and analyzed in triplicate under vacuum.

\section{Statistical analysis}

Data were analyzed according to Pimentel-Gomes and Garcia (2002). They were subjected to regression analysis ( $P$ $<0.05$ ), with the aid of the software Sisvar 5.6 (Ferreira, 2011). In the regression analysis, the best fit model was selected according to the criteria: biological explanation, significant regression, non-significant regression deviations and coefficient of determination.

\section{Conclusions}

The application of glyphosate (up to $8,640 \mathrm{~g}$ ae ha-1) or glufosinate (up to 6,000 ai ha-1) did not reduce yield and 100 -grain mass, nor did it influence the nutrient content in the grain of maize bearing cp4epsps and pat genes. This shows the high selectivity of these herbicides.

Nonetheless, crop injury and reduction in height were observed in maize plants for herbicide application. This indicates the risks of using herbicides above the rates recommended in the package insert, despite the absence of deleterious effects on yield.

\section{References}

Albrecht AJP, Albrecht LP, Barroso AAM, Cesco VJS, Krenchinski FH, Silva AFM, Victoria Filho R (2018) Glyphosate tolerant soybean response to different management systems. J Agric Sci. 10(1):204-216.

Albrecht AJP, Albrecht LP, Barroso AAM, Victoria Filho R (2014) RR2 corn and glyphosate: a review. Rev Bras Herb. 13(1):58-67.

Albrecht AJP, Silva AFM, Albrecht LP, Giovanelli BF, Ghirardello GA, Aiello LHF, Victoria Filho R (2016) Aplicação de diferentes manejos, formulações e doses de glyphosate, sobre o desenvolvimento do milho RR2. J Agron Sci. 5(2):114-124.

Albrecht LP, Albrecht AJP, Silva AFM, AAM Barroso (2021) Manejo de organismos geneticamente modificados tolerantes a herbicidas. In: Barroso AAM, Murata T (eds) Matologia: estudos sobre plantas daninhas. Fábrica da Palavra, Jaboticabal.

Bredemeier C, Mundstock CM (2000) Regulação da absorção e assimilação do nitrogênio nas plantas. Cienc Rural. 30(2):365-372.

Correia NM, Santos EA (2013) Foliar levels of macro and micronutrients in glyphosate-tolerant corn submitted to herbicides. Semina Cienc Agrar. 34(6):3165-3172.

Costa FR, Rech R, Duke SO, Carvalho LB (2018) Lack of effects of glyphosate and glufosinate on growth, mineral content, and yield of glyphosate-and glufosinate-resistant maize. GM Crop Food. 9(4):189-198.

Ferreira DF (2011) Sisvar: a computer statistical analysis system. Cienc Agrotec. 35(6):1039-1042.

Ganie ZA, Jhala AJ (2017) Interaction of 2,4-D or dicamba with glufosinate for control of glyphosate-resistant giant ragweed (Ambrosia trifida L.) in glufosinate-resistant maize (Zea mays L.). Front Plant Sci. 8:1207.

Ganie ZA, Lindquist JL, Jugulam M, Kruger GR, Marx DB, Jhala AJ (2017) An integrated approach to control glyphosateresistant Ambrosia trifida with tillage and herbicides in glyphosate-resistant maize. Weed Res. 57(2):112-122.

Giovanelli BF, Silva AFM, Albrecht AJP, Aiello LHF, Ghirardello GA, Albrecht LP Victoria Filho R (2018) Selectivity of herbicides applied separately or in combination in the post emergence of RR2 maize. Braz J Agric. 93(1):47-57.

Krenchinski FH, Albrecht AJP, Cesco VJS, Rodrigues DM, Pereira VGC, Albrecht LP, Carbonari CA, Victoria Filho R (2018a) Post-emergent applications of isolated and combined herbicides on corn culture with cp4-epsps and pat genes. Crop Prot. 106:156-162.

Krenchinski FH, Carbonari CA, Cesco VJS, Albrecht AJP, Arcuri MDLC, Maia IG, Velini ED (2018b) Glufosinate resistance level is proportional to phosphinothricin acetyltransferase gene expression in glufosinate-resistant maize. J Agric Food Chem. 66(48):12641-12650.

Lorenzi H (2014) Manual de identificação e controle de plantas daninhas: plantio direto e convencional, 7th ed. Instituto Plantarum, Nova Odessa. 
Matsuoka T, Kuribara H, Akiyama H, Miura H, Goda $Y$, Kusakabe Y, Isshiki K, Toyoda M, Hino A (2001) A multiplex PCR method of detecting recombinant DNAs from five lines of genetically modified maize. J Food Hyg Soc Jpn. 42(1):24-32.

Moreira MS, Nicolai M, Carvalho SJP, Christoffoleti PJ (2007) Glyphosate-resistance in Conyza canadensis and $C$. bonariensis. Planta Daninha. 25(1):157-164.

Môro FV, Damião Filho CF (1999) Alterações morfoanatômicas das folhas de milho submetidas à aplicação de nicosulfuron. Planta Daninha. 17(3):331-337.

Murakami T, Anzai H, Imai S, Satoh A, Nagaoka K, Thompson CJ (1986) The bialaphos biosynthetic genes of Streptomyces hygroscopicus: molecular cloning and characterization of the gene cluster. Mol Gen Genet. 205(1):42-53.

Oliveira Júnior RS (2011) Mecanismos de ação dos herbicidas. In: Oliveira Júnior RS, Constantin J, Inoue MH (eds) Biologia e manejo de plantas daninhas. Omnipax, Curitiba.

Pimentel-Gomes F, Garcia CH (2002) Estatística aplicada a experimentos agronômicos e florestais: exposição com exemplos e orientações para uso de aplicativos. Fealq, Piracicaba.

Reddy KN, Cizdziel JV, Williams MM, Maul JE, Rimando AM, Duke SO (2018) Glyphosate resistance technology has minimal or no effect on maize mineral content and yield. J Agric Food Chem. 66(39):10139-10146.

Ridley WP, Sidhu RS, Pyla PD, Nemeth MA, Breeze ML, Astwood JD (2002) Comparison of the nutritional profile of glyphosate-tolerant corn event NK603 with that of conventional corn (Zea mays L.). J Agric Food Chem. 50(25):7235-7243.
Rizzardi MA, Fleck NG, Agostinetto D, Balbinot Júnior AA (2003) Herbicides action in plant defense mechanisms to pathogens. Cienc Rural. 33(5):957-965.

Rodrigues BN, Almeida FS (2018) Guia de herbicidas, 7th ed. Londrina, Ed. Authors.

Sidhu RS, Hammond BG, Fuchs RL, Mutz JN, Holden LR, George B, Olson T (2000) Glyphosate-tolerant corn: The composition and feeding value of grain from glyphosatetolerant corn is equivalent to that of conventional corn (Zea mays L.). J Agric Food Chem. 48(6):2305-2312.

Silva AFM, Albrecht AJP, Giovanelli BF, Ghirardello GA, Damião VW, Albrecht LP, Victoria Filho R (2017) Seletividade de herbicidas isolados e em associações para milho RR2/LL ${ }^{\oplus}$. Rev Bras Herb. 16(1):60-66.

Soltani N, Shropshire C, Sikkema PH (2018) Tank mixture of glyphosate with 2,4-D accentuates 2,4-D injury in glyphosate-resistant corn. Can J Plant Sci. 98(4):889-896.

Stiegelmeier E, Costa L, Oliveira V (2016) Manejo de plantas daninhas: o problema econômico. Proc Series Braz Soc Comput Appl Math. 4(1):010060.

Taiz L, Zeiger E (2010) Plant physiology, 5th ed. Sinauer Associates, Sunderland.

Takano HK, Beffa R, Preston C, Westra P, Dayan FE (2019) Reactive oxygen species trigger the fast action of glufosinate. Planta. 249(6):1837-1849.

Velini ED, Osipe R, Gazziero DLP (1995) Procedimentos para instalação, avaliação e análise de experimentos com herbicidas. SBCPD, Londrina.

Zobiole LHS, Kremer RJ, Oliveira Júnior RS, Constantin J (2012) Glyphosate effects on photosynthesis, nutrient accumulation, and nodulation in glyphosate-resistant soybean. J Plant Nutr Soil Sci. 175(2):319-330. 